\title{
Detection and Exclusion of Alcoholism in Men on the Basis of Clinical Laboratory Findings ${ }^{1}$ )
}

\author{
By D. Stamm, E. Hansert and W. Feuerlein \\ Max Planck Institute for Psychiatry, Munich
}

(Received December 27, 1982/October 3, 1983)

In honour of Prof. Dr. Dr. h.c. mult. Adolf Butenandt on the occasion of his eightieth birthday

Summary: Alcoholism is a common disease; it is found in $10 \%$ to $15 \%$ of all patients admitted to general hospitals.

There is no single characteristic finding, but on the other hand, changes as compared with normal values have been reported in the literature for more than 30 frequently assayed clinical chemical and haematological parameters.

In the project reported here all 24 clinical chemical parameters and all 8 haematological parameters frequently assayed were studied in each of 82 hospitalized men with a confirmed diagnosis of alcoholism.

The diagnosis of alcoholism was made on the basis of the Munich Alcoholism Test (MALT) together with the following standardized assessments and examinations: past history, an alcohol questionnaire, general physical examination and neurological examination. All forms were filled in completely.

All steps in the clinical laboratory investigations were standardized, and all were subject to ongoing reliability control.

The clinical problem is usually not to differentiate alcohol abusers or alcoholics from healthy persons but rather to identify the alcoholics among a population of patients with a variety of illnesses.

For this reason $\overline{70}$ patients from two hospitals who were clearly neither alcohol abusers nor alcoholics were studied in exactly the same manner as the alcoholics.

In this combined group of 152 hospitalized patients significant differences were found in the distribution of the values for the alcoholics and the non-alcoholics for the following clinical chemical and haematological parameters: at the $0.1 \%$ level $\gamma$-glutamyltransferase, aspartate aminotransferase, urea, creatinine and mean corpuscular volume (MCV), and at the $1 \%$ level glutamate dehydrogenase, alanine aminotransferase and alkaline phosphatase.

From these eight parameters those combinations of between two and six parameters were selected that discriminated best between the alcoholics and the non-alcoholics. Using conventional decision limits the following was found: For the alcoholics two or more of the results for the following five parameters were outside the decision limits given in parentheses: $\gamma$-glutamyltransferase $(\geqslant 28 \mathrm{U} / 1)$, aspartate aminotransferase $(\geqslant 18 \mathrm{U} / \mathrm{l})$, alanine aminotransferase $(\geqslant 22 \mathrm{U} / \mathrm{l}), \mathrm{MCV}(\geqslant 96 \mathrm{fl})$, creatinine $(\leqslant 66.3 \mu \mathrm{mol} / \mathrm{l})$. The diagnostic sensitivity (alcoholics) is $85 \%$, the diagnostic specificity (non-alcoholics) is $64 \%$.

For the non-alcoholics three or fewer results were outside the decision limits given in parentheses: $\gamma$-glutamyltransferase $(<28 \mathrm{U} / \mathrm{l})$, aspartate aminotransferase $(<18 \mathrm{U} / \mathrm{l}), \mathrm{MCV}(<96 \mathrm{fl})$, creatinine $(>66.3 \mu \mathrm{mol} / \mathrm{l})$, urea-N (>5.0 mmol/h).

1) This research project was partially supported by funds provided by the Bayerisches Staatsministerium für Arbeit und Sozialordnung (Bavarian State Ministry of Labour and Welfare). 
With the decision limits given above and this combination of parameters the diagnostic specificity (non-alcoholics) is $96 \%$ and the diagnostic sensitivity (alcoholics) is $50 \%$.

This procedure thus enables the detection and exclusion of alcoholism in men on the basis of clinical laboratory findings.

By optimizing the decision limits, the diagnostic test criteria sensitivity, specificity and efficiency can be improved. Optimized decision limits for the discrimination of definite alcoholics from other patients who are definitely not alcoholics are shown in tables 3-14 to 3-16. A sensitivity (alcoholics) of $86 \%$ and a specificity (non-alcoholics) of $87 \%$ and thus an efficiency of 173 are obtained if the decision limits are fixed as follows and individuals are diagnosed as alcoholics if they have at least five results within these limits: $\gamma$-glutamyltransferase $\geqslant 27 \mathrm{U} / 1$, aspartate aminotransferase $\geqslant 9 \mathrm{U} / 1$, aspartate/alanine aminotransferase $\geqslant 0.63, \mathrm{MCV}$ $\geqslant 89 \mathrm{fl}$, creatinine $\leqslant 70.7 \mu \mathrm{mol} / \mathrm{l}$ and urea- $\mathrm{N} \leqslant 6.4 \mathrm{mmol} / \mathrm{l}$.

Findings in recent papers on clinical chemical and haematological markers of alcohol abuse are compared with the findings in this study regarding both methodology and information obtained. A realistic picture is obtained only if alcoholics are compared with other patients who are not alcoholics, not if they are compared with "healthy persons". A complete separation between alcoholics and non-alcoholics in patient populations based on the parameters evaluated in this study is not possible with any procedure.

Corresponding data for a population of female alcoholics and non-alcoholics have been collected and are now being evaluated.

\section{Erkennung oder Ausschluß des Alkoholismus bei Männern aufgrund klinisch-chemischer Befunde}

Zusammenfassung: Der Alkoholismus ist eine häufige Erkrankung; seine Prävalenz bei den Patienten Innerer Kliniken beträgt 10 bis $15 \%$.

Einerseits gibt es keinen charakteristischen Befund für den Alkoholismus, andererseits sind für alle diese Fälle Veränderungen gegenüber der Norm für mehr als 30 der häufig untersuchten klinisch-chemischen und hämatologischen Kenngrößen in der Literatur beschrieben.

In der vorliegenden Arbeit wurden bei 82 Patienten (Männer) mit sicher diagnostiziertem Alkoholismus gleichzeitig alle 24 klinisch-chemischen Kenngrößen und alle 8 hämatologischen Kenngrößen untersucht.

Die Diagnose des Alkoholismus erfolgte aufgrund des Münchner Alkoholismustests (MALT) sowie folgender standardisierter vollständiger Erhebungen oder Untersuchungen: Anamnese, Alkoholerhebungsbogen, internistische Untersuchung und neurologische Untersuchung.

Alle Teilschritte der klinisch-chemischen Untersuchungen waren standardisiert und unterlagen einer ständigen Zuverlässigkeitskontrolle.

Die klinische Fragestellung lautet meistens nicht, Patienten mit Alkoholabusus oder Alkoholismus von Ge=sunden zu unterscheiden, sondern sie verlangt, unter Patienten mit anderen Erkrankungen die Alkoholiker zu erkennen.

Es wurden deswegen aus zwei Krankenhäusern 70 Patienten mit anderen Erkrankungen, bei denen sicher kein Alkoholabusus oder Alkoholismus bestand (Nicht-Alkoholiker), in genau derselben Weise wie die Alkoholiker untersucht.

Bei diesen 152 Krankenhauspatienten bestanden signifikante Unterschiede in der Vèrteilung der Werte bei Alkoholikern und Nicht-Alkoholikern für die folgenden klinisch-chemischen und hämatologischen KenngröBen: Auf dem 0,1\%-Niveau $\gamma$-Glutamyltransferase, Aspartat-aminotransferase, Harnstoff, Kreatinin, mittleres Erythrocytenvolumen (MCV), und auf dem 1\%-Niveau Glutamatdehydrogenase, Alanin-aminotransferase, alkalische Phosphatase.

Es wurden aus diesen Kenngrößen diejenigen Kombinationen von 2 bis 6 Kenngrößen herausgesucht, die bei den Patienten am besten die Alkoholiker von den Nicht-Alkoholikern diskriminieren. Bei der Verwendung von konventionellen Entscheidungsgrenzen gilt: Bei Alkoholikern werden 2 oder mehr Ergebnisse außerhalb der in Klammern angegebenen Entscheidungskriterien bei folgenden 5 Kenngrößen gefunden: $\gamma$-Glutąmyl-

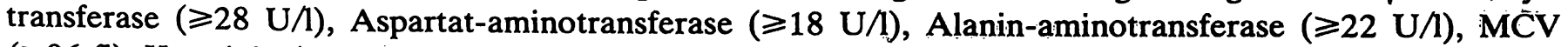
$(\geqslant 96 \mathrm{fl})$, Kreatinin $(\leqslant 66,3 \mu \mathrm{mol} / 1)$. Die diagnostische Sensitivität (Alkoholiker) ist $85 \%$, die diagnostische Spezifität (Nicht-Alkoholiker) 64\%. 
Bei Nicht-Alkoholikern werden 3 oder weniger Ergebnisse außerhalb der in Klammern angegebenen Entscheidungsgrenzen gefunden: $\gamma$-Glutamyltransferase (<28 U/l), Aspartat-aminotransferase (<18 U/l), MCV ( $<96 \mathrm{fl})$, Kreatinin ( $>66,3 \mu \mathrm{mol} / \mathrm{l})$, Harnstoff-N $(>5,0 \mathrm{mmol} / \mathrm{l})$.

Die diagnostische Spezifität (Nicht-Alkoholiker) beträgt bei dieser Kombination bei den vorgegebenen Entscheidungsgrenzen $96 \%$ und die diagnostische Sensitivität (Alkoholiker) $50 \%$.

Danach ist es möglich, aufgrund klinisch-chemischer Befunde bei Männern einen Alkoholismus zu erkennen oder auszuschließen.

Durch eine Optimierung der Entscheidungsgrenzen können die diagnostischen Prüfkriterien Sensitivität oder Spezifität oder Effizienz noch verbessert werden. Die optimierten Entscheidungsgrenzen für die Diskrimination der sicheren Alkoholiker von anderen Patienten, die sicher keine Alkoholiker sind, werden in den Tabellen 3-14 bis 3-16 mitgeteilt. Dabei werden bei einer Sensitivität (Alkoholiker) von $86 \%$ und einer Spezifität (Nicht-Alkoholiker) von 87\% eine Effizienz von 173 erreicht, wenn die Entscheidungsgrenzen wie folgt festgelegt und Probanden als Alkoholiker diagnostiziert werden, wenn sie mindestens fünf Ergebnisse innerhalb dieser Grenzen aufweisen: $\gamma$-Glutamyltransferase $\geqslant 27 \mathrm{U} / 1$, Aspartat-aminotransferase $\geqslant 9$ U/1, Aspartat-/Alanin-aminotransferase $\geqslant 0,63$, mittleres Erythrocytenvolumen $(\mathrm{MCV}) \geqslant 89 \mathrm{fl}$, Kreatinin $\leqslant 70,7 \mu \mathrm{mol} / 1$ und Harnstoff- $\mathrm{N} \leqslant 6,4 \mathrm{mmol} / \mathrm{l}$.

Arbeiten der letzten Jahre über klinisch-chemische und hämatologische „Marker“ für Alkoholabusus werden mit den vorliegenden Daten methodisch und sachlich kritisch verglichen. Ein realistisches Bild ergibt sich nur aus den Vergleich von Alkoholikern mit anderen Patienten, die keine Alkoholiker sind, aber nicht aus dem Vergleich mit „Gesunden“. Eine vollständige Trennung von Alkoholīkern und Nicht-Alkoholikern in Patientenpopulationen ist bei unseren Daten mit keinem Verfahren möglich.

Die Untersuchungen bei Frauen sind abgeschlossen und werden ausgewertet.

\section{Introduction and Description of the Problem}

Alcoholism is a common disease. The prevalence among hospital patients who have been admitted for reasons other than drunkenness is between 10 and 15 percent $(1,2)$.

By alcoholism is meant here excessive consumption of alcohol leading to a disturbance of physical, mental and/or social function. This definition is consistent with the 1952 definition of the World Health Organization and with the term "alcohol-related disabilities" used by Edwards et al. (3). The development of alcohol dependence is intentionally not discussed in this paper.

Since once consumed alcohol can reach virtually all body cells, alcohol abuse leads to metabolic, functional and sometimes even irreversible anatomical changes in numerous organs $(4,5,6)$. The symptoms of these changes are extremely diverse, variable and, frequently, uncharacteristic. Therefore, intensive efforts have been made to develop methods for the detection and exclusion of alcoholism.

Up to now no single characteristic symptom has been found on which to base a diagnosis of alcoholism.
Since 1977 there has been a reliable "combination" test for the detection of alcoholism $(7,8)$, the Munich Alcoholism Test (MALT). This test consists of two parts, the first requiring a self-rating by the patient (part $S$ ) and the second an assessment by a physician (part F) after a thorough examination of the patient. The two parts must be evaluated together. Part F contains one clinical chemistry criterion (the result for at least one of the three parameters aspartate aminotransferase, alanine aminotransferase and $\gamma$-glutamyltransferase must be outside of the normal range). For methodological reasons this criterion was omitted when evaluating the data in part $F$ for use in this study.

The MALT requires the cooperation of the patient for part S. However, since alcoholism is an illness that patients tend to conceal both from themselves and from relatives for as long as possible, questions that could indicate the presence of alcoholism are answered inaccurately by uncooperative patients.

In clinical work a technique is therefore urgently needed that enables both the detection and the exclusion of alcoholism without interviewing the patient and his or her relatives. 
The test developed by Shaw \& Lieber (9) based on the ratio of plasma $\alpha$-amino- $n$-butyric acid to leucine $(\mathrm{A} / \mathrm{L})$ is unsuitable as a screening test because of the time-consuming analytical procedure. This test detects only 80 percent of alcoholics and produces false positive results 2 percent of the time. Furthermore, it can be carried out only in specialized laboratories and is thus not available for use in routine diagnosis. The ratio is dependent on diet and is altered by liver disease. In addition, the $\mathrm{A} / \mathrm{L}$ ratio cannot be used as a screening test for alcoholism in populations that are heterogeneous with respect to nutrition or the extent of liver disease (5).

Thus there is still an urgent need for a test or a combination of tests for the detection of alcoholism that can be carried out easily and at any time both in hospitals and in physicians' offices.

Changes in a great many clinical chemical parameters have been observed in connection with alcoholism. These have been discussed in a previous paper on excessive consumption of alcohol as a biological influence factor (10). It is demonstrated clearly in that paper that the detection or exclusion of alcoholism by assessment of a single clinical chemical parameter, i.e. on the basis of a single clinical laboratory finding, is not possible. This observation led to the multivariate assessment of the same analytical results, which is the subject of the present paper.

In recent years a number of studies have also been published on combinations of clinical laboratory findings for the detection and exclusion of alcoholism (see Section 3.3). However, the findings in these studies are not comparable for the reasons given in the previous paper (10).

A group of known alcoholics was used in the present study. The subjects were all interviewed by a standard procedure, and all were given a thorough physical examination. The purpose of the study was to determine, with the highest possible probability of accuracy, those clinical chemical parameters that enable discrimination not only between these alcoholics and healthy persons but also between these alcoholics and patients with other disorders from the same population. The detection and exclusion of alcoholism are both dependent on diagnostic sensitivity and diagnostic specificity.

Those clinical chemical parameters were favoured that can be determined in all hospitals and in as many physicians' offices as possible. This would enable an early diagnosis or suspected diagnosis of alcoholism without the patient's cooperation.
This goal was achieved for a group of hospitalized men using six clinical chemical parameters. The present paper is a report on this project. The programme developed is now being validated on suitable patient populations in hospital departments of internal medicine.

\section{Purpose of the Study and Experimental Design}

\subsection{Purpose of the study}

\subsubsection{Detection of alcoholism}

The goal here is as high a diagnostic sensitivity as possible coupled with an adequate level of specificity. This would permit the diagnosis of suspected alcoholism. The diagnosis could then be confirmed with the appropriate special investigations.

If it is known that a patient is an alcoholic then this can be taken into consideration when treating other disorders (e.g. by prescribing a higher dosage of a medication or a different drug). If alcoholism could be detected at the beginning of an organic or mental disorder the diagnostic process could be greatly simplified and thus also shortened.

The problem is not to differentiate alcoholics from "healthy" persons but rather from other patients who are not alcoholics, for example those who have chronic hepatitis or biliary cirrhosis, and thus for whom certain clinical parameters äre outside the reference interval for healthy persons.

\subsubsection{Exclusion of alcoholism}

The goal here is as high a diagnostic specificity as possible with adequate sensitivity. Many pathological findings and many disorders can be caused by alcoholism $(4,5,6)$. Because of the high prevalence of alcoholism among hospitalized patients but also in the general population, it would be very helpful if alcoholism could be excluded as the cause with a sufficiently high degree of probability via clinical laboratory investigations.

\subsubsection{Monitoring of treatment in alcoholics}

It would be most useful in the treatment of alcoholics to have a procedure for the detection of renewed alcohol consumption for a longer period after the event than is currently possible by heasuring serum 
ethanol. In addition, an attempt should be made to detect those patients whose alcohol consumption has already resulted in isolated physical damage but not to the extent that the MALT criteria for alcoholism are fulfilled.

\subsection{Subjects}

The analytical results that served as the basis for this study were also used in another part of the same project. They were obtained from carefully evaluated patients and thus from patients whose diagnosis with regard to alcoholism was definite. The details have been reported elsewhere (10).

A few points should be stressed here, however.

For the questions raised in this study a reference sample group of "healthy" persons would not have been the most meaningful control group. Rather, it was essential that comparisons also be made with non-alcoholics who had been selected from the same hospital population as the alcoholics. Therefore, the patients in this study were selected from a general city hospital (Munich-Schwabing City Hospital), a psychiatric hospital (Haar Regional Hospital) and (alcoholics only) a hospital specializing in the treatment of alcoholism (Annabrunn Alcoholism Treatment Centre).

\subsection{Statistical evaluation}

The following kinds of statistical evaluation were carried out:

1. Comparison of the results for alcoholics and healthy persons. The decision limits used were the upper and lower limits of the relevant reference interval $(11,12)$ and the location parameter for healthy persons. In the previous paper (10) these comparisons were made only for individual constituents, whereas in the present study combinations of constituents were assessed.

2. Comparison of the results for alcoholics and nonalcoholics, both groups of subjects having been selected from the same populations of hospitalized patients. The decision limits were the same as in the comparisons with healthy persons. The comparisons were made for both individual constituents and combinations of constituents.

3. Optimization of the decision limits with regard to the diagnostic criteria sensitivity, specificity and efficiency.

\section{Materials and Methods}

The patients and methods have been described in the report on another part of this project (10). The reader is therefore referred to the following sections of the report on the earlier study:

\subsection{Patient selection}

\subsection{Examination of the patients}

2.3 Clinical chemical parameters studied, analytical methods used and reliability criteria

2.4 Biological influence factors and interference factors

Further information is necessary only regarding the statistical procedures used.

\subsection{Statistical procedures}

Numerous comparisons were made in connection with this project. The statistical procedures used in these comparisons are listed below.

\subsubsection{Comparison of the results for alcoholics and healthy persons}

Here the results were compared using the relevant reference interval for healthy persons. This is a purely descriptive procedure, with the number and percentage of results above and below the reference interval being determined.

In addition, the location of the results for the alcoholics was compared with the location parameter of the reference values for the healthy persons in order to detect any systematic deviation; significance was assessed using the sign test (13).

\subsubsection{Comparison of the results for alcoholics and non-alcoholics}

For each individual constituent the distribution of the results for the alcoholics was compared with the distribution for the non-alcoholics using the chi-square test.

Since in these comparisons the number of degrees of freedom (number of classes minus 1) and thus the critical values were not the same for all constituents, a standardized parameter $\widetilde{\mathrm{X}}^{2}$ was introduced where

$$
\widetilde{X}^{2}=\frac{X^{2}-f}{\sqrt{2 f}}
$$

and $f$ is the number of degrees of freedom.

For the values of $f$ occurring in this study a $\widetilde{\mathrm{X}}^{2}$ value of more than 3 can be regarded as indicating a significant difference at the $1 \%$ level and a value above 5 a significant difference at the $0.1 \%$ level. For $X^{2} \leqslant f, \widetilde{X}^{2}$ is defined as 0 .

In comparing combinations those parameters were selected where the distributions for the alcoholics and non-alcoholics showed the largest differences.

The differences between distributions of combinations were analysed only with regard to discrimination between alcoholics and non-alcoholics, not with regard to significance.

\subsubsection{Optimization of the decision limits}

The usual procedure for achieving optimal discrimination between two populations such as alcoholics and non-alcoholics is linear discriminant analysis. However, the application of this procedure with the analytical results obtained here did not yicld 
satisfactory results. This is not surprising since linear discriminant analysis is based on the model of normal distributions with identical matrices of covariance, i.e. especially with identical standard deviations for the individual values. Quadratic discriminant analysis, which is sometimes used, also assumes a normal distribution. But usually, and especially in this case, not even a normal distribution can be assumed, quite apart from identical standard deviations. Therefore a system was developed that is as simple as possible and still effective. This procedure is based on the direct transfer of the term "decision limit" to several dimensions and the division of the multidimensional space into simple discriminance areas defined by such multiple decision limits. A detailed description of this procedure and a discussion of its application are the subject of another paper (14). The fact that this simple method yielded substantially better results than the parametric procedure shows that, in contrast to the view sometimes expressed (15), the form of the distribution can have a decisive influence on the result of a parametric analysis.

A number of other well-known statistical procedures were also used in connection with this project. They are listed in table 2-1 according to the area of application.

\section{Results and Discussion}

The analytical results obtained for the alcoholics were compared with the reference intervals $(11,12)$ and location parameters of the analytical results obtained for healthy persons. Then the results for the alcoholics were compared with those for patients who were definitely not alcoholics, but who had been treated for some other problem on the same hospital wards as the alcoholics. This comparison and the in- formation obtained from it provide the basis for achieving the goals initially set. The comparisons and the strategies for investigation derived from them are a practical example of the models developed in general clinical chemistry $(17,18,19,20)$ and their applicability in connection with clinical questions.

Each section of results is followed immediately by a discussion of those results.

\subsection{Comparison of the analytical results for alcoholics and healthy persons}

Medical assessment of analytical results (21) usually involves a comparison with the reference interval (earlier termed "normal range") for a group of people considered to be healthy. Thus a transverse assessment is usually made $(22,21)$. Most of the published reports on changes in clinical chemical parameters in alcoholics are also based on this kind of comparison (l.c. (10) and Section 3.3). This was the case, too, for the group of alcoholics reported on by the present authors in the previous paper (10). An assessment was made of the percentage of the analytical results for the alcoholics above and below the reference interval or the location parameter for a representative sample of healthy persons.

The disorders found in the two groups of patients are listed in table 3-1.

Tab. 2-1. Special statistical evaluations.

\begin{tabular}{|c|c|c|}
\hline Question & Procedure & References \\
\hline 1. Normal distribution of individual constituents (alcoholics and non-alcoholics) & Sarkadi-Stoermer & (15a) \\
\hline 2. Comparison of the institutions for the 7 most important individual constituents & Kruskal-Wallis & $(16,13)$ \\
\hline $\begin{array}{l}\text { 3. Comparison alcoholics/non-alcoholics for } \\
\text { - Age } \\
\text { - Height } \\
\text { - Weight } \\
\text { - Difference between weight and ideal weight }\end{array}$ & $\begin{array}{l}\text { Chi-square } \\
\text { Wilcoxon-Mann-Whitney } \\
\text { Wilcoxon-Mann-Whitney }\end{array}$ & $\begin{array}{c}(16,13) \\
\cdots\end{array}$ \\
\hline $\begin{array}{l}\text { 4. Correlation between the } 7 \text { most important constituents } \\
\text { - Creatinine/body weight } \\
\text { - Urea/body weight }\end{array}$ & $\begin{array}{l}\text { Both product-moment correlation } \\
\text { and } \\
\text { Spearman rank correlation }\end{array}$ & (16) \\
\hline $\begin{array}{l}\text { 5. Comparison of the subjects with low/high MALT scores for the } 7 \text { most important } \\
\text { constituents (alcoholics and non-alcoholics) }\end{array}$ & Wilcoxon-Mann-Whitney & $(16,13)$ \\
\hline $\begin{array}{l}\text { 6. Comparison of the subjects without liver disease for } \\
-\gamma \text {-Glutamyltransferase } \\
- \text { MCV } \\
\text { - Creatinine }\end{array}$ & Wilcoxon-Mann-Whitney & $(16,13)$ \\
\hline $\begin{array}{l}\text { 7. Number of subjects (alcoholics) with liver disease within/outside the reference } \\
\text { limits for the } 7 \text { most important constituents }\end{array}$ & Description & \\
\hline
\end{tabular}


Tab. 3-1. Disorders found in the two groups of patients (more than one possible).

\begin{tabular}{lcc}
\hline Kind of disorder/organ & Alcoholics & Non-alcoholics \\
\hline No other physical disorder & 29 & - \\
Liver & 41 & 1 \\
Pancreas & 1 & 1 \\
Gastrointestinal tract & 4 & 7 \\
Blood and haematopoietic tissues & 1 & - \\
Neurological disorders & 4 & 3 \\
Mental disorders: & & \\
$\quad$ Alcohol delirium & 3 & - \\
Schizophrenia & - & 27 \\
Affective psychoses & - & 1 \\
Neuroses & - & 2 \\
Personality disorders & - & 3 \\
Suicide attempt & - & 3 \\
Chronic brain syndrome & 1 & - \\
$\quad$ Adjustment reaction & - & 3 \\
Mineral metabolism & - & - \\
Metabolic disorders & 9 & 7 \\
Endocrine disorders & - & 2 \\
Drug abuse & 4 & - \\
Kidneys & - & 4 \\
Orthopaedic disorders & 1 & 4 \\
Skin & 5 & - \\
Respiratiory system & 2 & 2 \\
Traumas & 1 & 1 \\
N = & 82 & 70 \\
\hline & & \\
\hline & &
\end{tabular}

\subsection{Comparison of alcoholics with other pa- tients}

The first step in comparing the analytical results for the alcoholics and non-alcoholics was to determine whether the distributions were significantly different. If there were significant differences between the distributions for alcoholics and non-alcoholics for a given constituent, then the diagnostic importance of that constituent in the detection and exclusion of alcoholism was assessed.

This assessment consisted of determining the diagnostic sensitivity, diagnostic specificity and diagnostic efficiency, each expressed as a percentage.

Diagnostic sensitivity $(\%)=$

$$
\frac{\text { number of positive findings }}{\text { number of alcoholics }} \times 100
$$

Diagnostic specificity $(\%)=$

$\frac{\text { number of negative findings }}{\text { number of non-alcoholics }} \times 100$
Diagnostic efficiency is defined in this paper as the sum of diagnostic sensitivity and diagnostic specificity: ${ }^{2}$ )

$$
\text { sensitivity }+ \text { specificity }=\text { efficiency }
$$

Since sensitivity and specificity are given as percentages, the highest possible value for diagnostic efficiency is 200. For quantitative tests the decision about whether a finding is positive or negative is based on a comparison with a decision limit. For transverse assessment in medicine this usually takes the form of a comparison with what is termed the reference interval. The initial decision limits used were therefore parameters for a reference population of healthy persons (upper and lower limits of the reference interval and the location parameter). First, each clinical chemical parameter was assessed alone.

Since it is well known that the diagnostic validity of clinical chemical tests can be improved by combining two or more tests, various combinations were then assessed for their diagnostic efficiency.

Finally, an attempt was made to optimize the diagnostic importance of individual investigations and combinations of investigations by altering the decision limits.

3.2.1 Differences between the distributions of analytical results for the alcoholics and the non-alcoholics

The differences were assessed with the chi-square test. A standard measure was introduced because of the different degrees of freedom for the different constituents (see Section 2.5.2 above). The results of this assessment (performed as described in Section 2.5.2) are shown in table 3-2. The level of efficiency with optimal decision limits (14 and Section 5.2) is given only for those constituents for which the differences between the distributions were significant at the $1 \%$ level or better. The significant difference at the $0.1 \%$ level in the distributions for alcoholics and non-alcoholics for creatinine is of greatest interest: For all the other parameters with significant differences between the distributions for alcoholics and non-alcoholics, the altered values in the alcoholics were already evident using the conventional assessment system, as demonstrated in tables 3-1 and 3-2 of the previous paper (10).

2) Another common definition of efficiency is the percentage of "correct" findings in the total sample. The reasons for using the above definition instead are discussed clscwhere (14). For subsamples of the same size the definitions are the same cxcept for a factor of 2 . 
Tab. 3-2. Comparison of the distributions of the analytical results for alcoholics and non-alcoholics.

\begin{tabular}{|c|c|c|c|c|c|c|c|}
\hline \multirow[t]{2}{*}{ Constituent } & \multirow[t]{2}{*}{ (Unit) } & \multirow[t]{2}{*}{$\widetilde{\mathrm{X}}^{2}$} & \multirow{2}{*}{$\begin{array}{l}\text { Signifi- } \\
\text { cance } \\
1 \%:^{*} \\
0.1 \%:^{* *}\end{array}$} & \multirow[t]{2}{*}{$\begin{array}{l}\text { Maximum } \\
\text { efficiency }\end{array}$} & $\begin{array}{l}\text { Optimized } \\
\text { decision limit }\end{array}$ & \multicolumn{2}{|c|}{ Reference limits } \\
\hline & & & & & & $\begin{array}{c}\text { lower } \\
.\end{array}$ & upper \\
\hline Haemoglobin & $(g / l)$ & 2.74 & & & & & \\
\hline Haematocrit & (1) & 0 & & & & & \\
\hline Erythrocytes & $\left(10^{12} / 1\right)$ & 1.76 & & & & & \\
\hline MCV & (fl) & 5.18 & $* *$ & 138 & 95 & 80 & 96 \\
\hline $\mathrm{MCH}$ & (pg) & 3.91 & $*$ & 130 & 32 & & \\
\hline Reticulocytes & (1) & 0.95 & & & & & - \\
\hline Leukocytes & $\left(10^{9} / 1\right)$ & 0 & & & & & \\
\hline Granulocytes & $(\%)$ & 6.70 & $*$ & 124 & 1 & & \\
\hline Lymphocytes & $(\%)$ & 0.55 & & & & & \\
\hline Thrombocytes & $\left(10^{9} / 1\right)$ & 0 & & & & & \\
\hline Glucose & (mmol/l) & 0.16 & & & & & \\
\hline Total protein & $(g / 1)$ & 2.21 & & & & & \\
\hline Albumin fraction & (1) & 0.83 & & & & & \\
\hline Globulin fractions & & & & & & & \\
\hline$\alpha_{1-}$ & (1) & 0 & & & & & \\
\hline$\alpha_{2-}$ & (1) & 0 & & & & & \\
\hline$\tilde{\beta}-$ & (1) & 0.62 & & & & & \\
\hline$\gamma-$ & (1) & 0 & & & & & \\
\hline Bilirubin & $(\mu \mathrm{mol} / \mathrm{l})$ & 2.58 & & & & & \\
\hline Uric acid & $(\mu \mathrm{mol} / \mathrm{l})$ & 0 & & & & & \\
\hline Sodium & (mmol/l) & 0.31 & & & . & & \\
\hline Potassium & (mmol/l) & 0 & & & & & \\
\hline Calcium & (mmol/l) & 0 & & & & & \\
\hline Chloride & (mmol/l) & 0.64 & & & & & \\
\hline Phosphorus & $(\mathrm{mmol} / \mathrm{l})$ & 0.28 & & & & & \\
\hline Magnesium & $(\mathrm{mmol} / \mathrm{l})$ & 1.84 & & & & & \\
\hline Serum iron & $(\mu \mathrm{mol} / \mathrm{l})$ & 1.25 & & & & & \\
\hline Serum copper & $(\mu \mathrm{mol} / \mathrm{l})$ & 0 & & & & & \\
\hline Cholesterol & $(\mathrm{mmol} / \mathrm{l})$ & 0 & & & & & \\
\hline Triglycerides & $(\mathrm{mmol} / \mathrm{l})$ & 0 & & & & & \\
\hline Creatinine & $(\mu \mathrm{mol} / \mathrm{l})$ & 5.19 & $* *$ & 137 & 71 & 44 & 97 \\
\hline Urea-N & $(\mathrm{mmol} / \mathrm{l})$ & 6.78 & $* *$ & 135 & 4.3 & 2.1 & 7.8 \\
\hline$\gamma$-Glutamyltransferase & $(U / l)$ & 14.26 & $* *$ & 151 & 45 & 6 & 28 \\
\hline Aspartate aminotransferase & $(U / I)$ & 15.14 & $* *$ & 145 & 16 & $\because \cdots 2$ & 18 \\
\hline Alanine aminotransferase & $(U / I)$ & 3.28 & $*$ & 132 & 15 & 2 & 22 \\
\hline Cholinesterase & $(\mathrm{U} / \mathrm{l})$ & 0.25 & & & & & \\
\hline Alkaline phosphatase & $(\mathrm{U} / \mathrm{l})$ & 3.16 & * & 125 & 145 & 60 & 200 \\
\hline Glutamate dehydrogenase & $(\mathrm{U} / \mathrm{l})$ & 4.86 & $*$ & 132 & 1.6 & & 4 \\
\hline Creatine kinase & $(\mathrm{U} / \mathrm{l})$ & 0.69 & & & & & \\
\hline
\end{tabular}

If the distributions for a given constituent were significantly different, then the efficiency, assuming optimal decision limits, was determined (see Section 3.2.4). It was found that there was not always a correlation between the results of the chi-square test and the efficiency levels.

\subsubsection{Diagnostic sensitivity, diagnostic specificity and efficiency of individual findings}

Diagnostic sensitivity, specificity and efficiency were determined for each of the clinical chemical parameters studied as illustrated with $\gamma$-glutamyltransferase in table 3-3, assuming the usual decision limits (limits of the reference interval or location parameter of the reference values). As already pointed out, the diagnostic efficiency can have a maximum value of 200.

Table 3-4 shows all constituents for which the diagnostic efficiency was greater than or equal to 118 , assuming conventional decision limits.

1. Diagnostic sensitivity always refers to the alcoholics.

2. Diagnostic specificity always refers only to the non-alcoholics. 
Tab. 3-3. Determination of diagnostic sensitivity, specificity and cfficiency for the assay of $\gamma$-glutamyltransferase. $b=$ catalytic activity concentration (of $y$-glutamyltransferase)

\begin{tabular}{|c|c|c|c|c|c|}
\hline \multicolumn{3}{|c|}{ Alcoholics } & \multicolumn{3}{|c|}{ Non-alcoholics } \\
\hline No. & Code & $U / I$ & No. & Code & $U / I$ \\
\hline 1. & 6033 & 11 & 1. & 2641 & 8 \\
\hline 2. & 6023 & 13 & 2. & 2627 & 9 \\
\hline 3. & 4146 & 14 & 3. & 4631 & 9 \\
\hline 4. & 6062 & 16 & 4. & 4634 & 10 \\
\hline 5. & 2019 & 18 & 5. & 4632 & 10 \\
\hline 6. & 6032 & 18 & 6. & 2640 & 11 \\
\hline 7. & 6049 & 19 & 7. & 4609 & 11 \\
\hline 8. & $41^{\circ} 61$ & 20 & 8. & 4624 & 11 \\
\hline 9. & 2145 & 21 & 9. & 4633 & 11 \\
\hline 10. & 6055 & 21 & 10. & 4673 & 11 \\
\hline 11. & 6064 & 21 & 11. & 2602 & 12 \\
\hline 12. & 6066 & 22 & 12. & 2612 & 12 \\
\hline 13. & 6041 & 23 & 13. & 4625 & 12 \\
\hline 14. & 6030 & 25 & 14. & 4642 & 12 \\
\hline 15. & 6007 & 26 & 15. & 4665 & 12 \\
\hline 16. & 4184 & 27 & 16. & 4698 & 12 \\
\hline 17. & 4190 & 27 & 17. & 2649 & 13 \\
\hline 18. & 6052 & 27 & 18. & 2607 & 13 \\
\hline 19. & 4101 & 30 & 19. & 4668 & 13 \\
\hline 20. & 6040 & 30 & 20. & 4618 & 14 \\
\hline 21. & 6042 & 30 & 21. & 2608 & 14 \\
\hline 22. & 4114 & 31 & 22. & 4635 & 14 \\
\hline 23. & 2057 & 32 & 23. & 4704 & 14 \\
\hline 24. & 4201 & 32 & 24. & 4637 & 15 \\
\hline 25. & 6051 & 32 & 25. & 2648 & 16 \\
\hline 26. & 2036 & 35 & 26. & 2638 & 16 \\
\hline 27. & 2029 & 36 & 27. & 4703 & 16 \\
\hline 28. & 6045 & 39 & 28. & 4692 & 17 \\
\hline 29. & 4139 & 41 & 29. & 4694 & 17 \\
\hline 30. & 6044 & 41 & 30. & 4695 & 17 \\
\hline 31. & 4159 & 45 & 31. & 2652 & 18 \\
\hline 32. & 2038 & 45 & 32. & 2624 & 18 \\
\hline 33. & 2012 & 49 & 33. & 4636 & 19 \\
\hline 34. & 1002 & 50 & 34. & 2617 & 20 \\
\hline 35. & 6010 & 52 & 35. & 2619 & 20 \\
\hline 36. & 2028 & 56 & 36. & 4667 & 20 \\
\hline 37. & 2143 & 56 & 37. & 2631 & 22 \\
\hline 38. & 4202 & 57 & 38. & 2625 & 23 \\
\hline 39. & 1004 & 59 & 39. & 2637 & 23 \\
\hline 40. & 4158 & 60 & 40. & 2633 & 23 \\
\hline 41. & 6043 & 60 & 41. & 2650 & 23 \\
\hline 42. & 6050 & 62 & 42. & 2647 & 25 \\
\hline 43. & 6008 & 67 & 43. & 4678 & 25 \\
\hline 44. & 6021 & 72 & 44. & 2611 & 26 \\
\hline 45. & 6046 & 72 & 45. & 4623 & 26 \\
\hline 46. & 6048 & 77 & 46. & 4693 & 26 \\
\hline
\end{tabular}

\begin{tabular}{|c|c|c|c|c|c|}
\hline \multicolumn{3}{|c|}{ Alcoholics } & \multicolumn{3}{|c|}{ Non-ácoholics } \\
\hline No. & Code & $U / 1$ & No. & Code & $U / 1$ \\
\hline 47. & 6065 & 77 & 47. & 2644 & 26 \\
\hline 48. & 6063 & 80 & 48. & 4645 & 28 \\
\hline 49. & 4112 & 83 & 49. & 2632 & 28 \\
\hline 50. & 2024 & 93 & 50. & 4626 & 30 \\
\hline 51. & 6031 & 100 & 51. & 2651 & 30) \\
\hline 52. & 2017 & 100 & 52. & 2030 & 31 \\
\hline 53. & 4186 & 102 & 53. & 4652 & 32 \\
\hline 54. & 4102 & 104 & 54. & 4691 & 32 \\
\hline 55. & 6020 & 119 & 55. & 4616 & 32 \\
\hline 56. & 6047 & 124 & 56. & 4611 & 35 \\
\hline 57. & 2059 & 125 & 57. & 2613 & 38 \\
\hline 58. & 2027 & 132 & 58. & 2642 & 38 \\
\hline 59. & 2067 & 134 & 59. & 4654 & 39 \\
\hline 60. & 4200 & 147 & 60. & 4628 & 42 \\
\hline 61. & 6053 & 151 & 61. & 4627 & 42 \\
\hline 62. & 6006 & 170 & 62. & 2634 & 47 \\
\hline 63. & 4103 & 186 & 63. & 4653 & 58 \\
\hline 64. & 6061 & 190 & 64. & 4670 & 60 \\
\hline 65. & 2025 & 224 & 65. & 2620 & 60 \\
\hline 66. & 2035 & 248 & 66. & 4615 & 64 \\
\hline 67. & 4185 & 249 & 67. & 4705 & 77 \\
\hline 68. & 6009 & 250 & 68. & 2601 & 80 \\
\hline 69. & 4156 & 252 & 69. & 4655 & 136 \\
\hline 70. & 6022 & 253 & 70. & 4617 & 218 \\
\hline 71. & 4160 & 270 & & & \\
\hline 72. & 4151 & 282 & & & \\
\hline 73. & 2068 & 352 & & & \\
\hline 74. & 6054 & 360 & & & \\
\hline 75. & 2005 & 370 & & & \\
\hline 76. & 2015 & 450 & & & \\
\hline 77. & 2014 & 450 & & & \\
\hline 78. & 2039 & 484 & & & \\
\hline 79. & 1001 & 580 & & & \\
\hline 80. & 1003 & 670 & & & \\
\hline 81. & 2034 & 930 & & & \\
\hline 82. & 2056 & 1430 & & & \\
\hline
\end{tabular}

Example with conventional decision limits:

Diagnostic sensitivity $(\%)=$

$$
\frac{\text { Alcoholics with } b \geqslant 28 \mathrm{U} / 1}{\text { No. of alcoholics }} \times 100=\frac{64}{82} \times 100=78.0 \%
$$

Diagnostic specifity $(\%)=$

$\frac{\text { Non-alcoholics with } b<28 \mathrm{U} / !}{\text { No. of non-alcoholics }} \times 100=\frac{47}{70} \times 100=67.1 \%$

Diagnostic efficiency $=$

diagnostic sensitivity + diagnostic specificity $=$

$78.0+67.1=145.1$

Tab. 3-4. Diagnostic sensitivity, specificity and efficiency for individual constituents.

\begin{tabular}{|c|c|c|c|c|c|c|c|}
\hline Constituent & (Unit) & Abbreviation & Criterion & $\begin{array}{l}\text { Sensitivity } \\
(\%)\end{array}$ & Criterion & $\begin{array}{l}\text { Specificity } \\
(\%)\end{array}$ & Efficiency \\
\hline $\begin{array}{l}\gamma \text {-Glutamyltransferase } \\
\text { Aspartate aminotransferase } \\
\text { Urea-N } \\
\text { Creatinine } \\
\text { Mean corpuscular volume } \\
\text { Alanine aminotransferase }\end{array}$ & $\begin{array}{l}(U / \mathrm{l}) \\
(\mathrm{U} / \mathrm{l}) \\
(\mathrm{mmol} / \mathrm{l}) \\
(\mu \dot{\mathrm{mol}} / \mathrm{l}) \\
(\underline{\mathrm{l}}) \\
(\mathrm{U} / \mathrm{l})\end{array}$ & $\begin{array}{l}\gamma-G T \\
\text { GOT } \\
\text { urea-N } \\
\text { creat } \\
\text { MCV } \\
\text { GPT }\end{array}$ & $\begin{array}{l}\geqslant 28 \\
\geqslant 18 \\
\leqslant 5.0 \\
\leqslant 66.3 \\
\geqslant 96 \\
\geqslant 22\end{array}$ & $\begin{array}{l}78.0 \\
47.6 \\
80.5 \\
48.8 \\
72.8 \\
45.1\end{array}$ & $\begin{array}{l}<28 \\
<18 \\
>5.0 \\
>66.3 \\
<96 \\
<22\end{array}$ & $\begin{array}{l}6 \overline{7} .1 \\
91.4 \\
52.9 \\
84.3 \\
60.0 \\
72.9\end{array}$ & $\begin{array}{l}14 \overline{5} . \overline{2} \\
139.0 \\
133.6 \\
133.1 \\
132.8 \\
118.0\end{array}$ \\
\hline
\end{tabular}

In contrast to table 3-2, conventional decision limits have been used here, as is the case for all subsequent tables through 3-10. 
3. Both are dependent on the decision limit used (e.g. limit of the reference interval, location parameter of the reference values or some other decision limit). If non-alcoholics are replaced by healthy persons and the decision limit is held constant a different specificity usually results.

4. Thus diagnostic sensitivity and diagnostic specificity are completely independent of one another. Knowledge of the value of one of these diagnostic criteria does not provide any information about the value for the other (see example in table 3-3).

5. A particular level of efficiency is valid only for the combination of two specific distributions, in this case for the combination of the distributions for alcoholics and non-alcoholics.

\section{Detection and exclusion}

From the logical point of view the use of diagnostic sensitivity and diagnostic specificity is based on the exclusion principle, in analogy with statistical test procedures (14).

If a test based on positive results has a high sensitivity (as, for example, $92.6 \%$ in table $3-6$, constituent combination 10 , or $95.1 \%$ in table $3-16$ ), a negative test result signifies the exclusion of alcoholics, i.e. the detection of non-alcoholics. In this case a positive test result taken alone does not necessarily mean the detection of alcoholics. If the test has a high specificity (as, for example, $97.1 \%$ in table $3-7$, constituent combination 5 , or $95.7 \%$ in table $3-15$ ), a positive test result signifies the exclusion of non-alcoholics, i.e. the detection of alcoholics.

Here a negative test result taken alone does not necessarily mean the detection of non-alcoholics. A single test criterion can be used both to detect and to exclude alcoholics or non-alcoholics only if it has both sufficiently high sensitivity and sufficiently high specificity and thus sufficiently high efficiency. Otherwise different criteria must be used for detection and exclusion.

\subsubsection{Diagnostic sensitivity, specificity and efficiency of constituent combinations}

When differentiating between alcoholics and non-alcoholics on the basis of individual findings and conventional criteria (tab. 3-4), the highest level of efficiency was 145 and thus still unsatisfactory. It therefore seemed reasonable to try to obtain better discrimination by using combinations of findings.

Table 3-5 shows the combinations of positive findings found, including the number of alcoholics and non-alcoholics with each combination. There are numerous different patterns of findings, and it seemed useful to assess the efficiency of differentiation with these different patterns. Here it must be emphasized that the assessments were always made parallel to each other, not sequentially.

In the following, the findings for a subgroup of alcoholics and a subgroup of non-alcoholics serve to illustrate the kinds of information contained in table 3-5.

In the group of alcoholics $(n=82)$ with 3 positive findings $(\mathrm{k}=3)$ there are 18 alcoholics $\left(\mathrm{H}_{\mathrm{k}}\right)$. Of these 18 alcoholics, one-third had no elevation of $\gamma$ glutamyltransferase, and 4 had no positive liver findings at all. All alcoholics without elevated $\gamma$-glutamyltransferase had elevated MCV and a drop in either creatinine or urea or both. Of the 82 alcoholics, 65 had between 3 and 6 positive findings $\left(\mathrm{H}_{\mathrm{k}}^{*}\right)$.

In the group of non-alcoholics $(n=70), 20\left(\mathrm{H}_{\mathrm{k}}\right) \mathrm{had}$ 2 positive findings $(k=2)$ and 52 had 2 or fewer positive findings $\left(\mathrm{H}_{\mathrm{k}}^{* *}\right)$. Of these $52 ; 6$ had elevated $\gamma$-glutamyltransferase but no elevation of aspartate aminotransferase or alanine aminotransferase; 2 had elevated MCV, 1 decreased creatinine and 3 a drop in urea- $\mathrm{N}$ below the location parameter of the reference sample group.

Table 3-5 also shows that $2\left(\mathrm{H}_{\mathrm{k}}\right)$ of the 82 alcoholics had no pathological findings at all $(\mathrm{k}=0)$. Among the non-alcoholics the number was 14 . In addition, 18 of the 82 alcoholics did not have elevated $\gamma$-glutamyltransferase, 26 did not have elevated MCV and 6 had no elevation in either. Both $\gamma$-glutamyltransferase and MCV were elevated in 44 of the 82 alcoholics. 
k: Number of positive findings (e.g. 4)

$\mathrm{H}_{\mathrm{k}}$ : Number of subjects with $\mathrm{k}$ positive findings (e.g. 22 alcoholics and 8 non-alcoholics had 4 positive findings)

$\mathrm{H}_{\mathrm{ki}}$ : Number of subjects with a given pattern (e.g. 3 alcoholics but no non-alcoholics had positive findings for the combination $\gamma$-glutamyltransferase, aspartate aminotransferase. MCV and urea)

$\mathrm{H}_{\mathrm{k}}^{*}$ : Number of subjects with at least $k$ positive findings (e.g. 47 alcoholics had 4,5 or 6 positive findings)

$\mathrm{H}_{\mathrm{k}}^{* *}$ : Number of subjects with $k$ positive findings at the most (e.g. 70 non-alcoholics had 1, 2, 3 or 4 positive findings)

Abbreviations and decision limits as in Tab. 3-4.

\begin{tabular}{|c|c|c|c|c|c|c|c|c|c|c|}
\hline k & $H_{k}$ & $H_{k}^{*}$ & $\mathbf{H}_{\mathbf{k i}}$ & 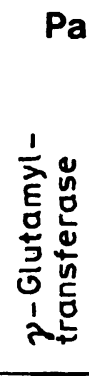 & 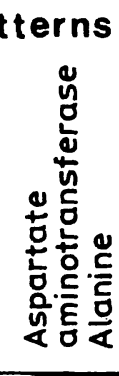 & 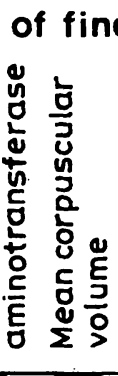 & $\begin{array}{l}\text { lings } \\
\end{array}$ & $\mathbf{H}_{\mathbf{k i}}$ & $\mathbf{H}_{\mathbf{k}}^{* *}$ & $H_{k}$ \\
\hline 6 & 8 & 8 & 8 & $1 \therefore$ & & 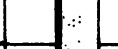 & & & 70 & 0 \\
\hline 5 & 17 & 25 & $\begin{array}{r}1 \\
2 \\
12 \\
2 \\
\end{array}$ & {$\left[\begin{array}{l}\vdots \\
\vdots \\
\vdots\end{array}\right.$} & $\overline{7}$ & 6 & & & 70 & 0 \\
\hline 4 & 22 & 47 & $\begin{array}{l}3 \\
3 \\
1 \\
2 \\
4 \\
9 \\
\end{array}$ & .0 & & & & $\begin{array}{l}1 \\
2 \\
2 \\
\end{array}$ & 70 & B \\
\hline 3 & 18 & 65 & $\begin{array}{l}1 \\
2 \\
5 \\
4 \\
1 \\
1 \\
4 \\
\end{array}$ & 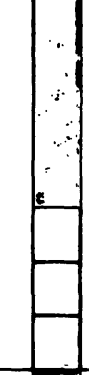 & & & & 5 & 62 & 10 \\
\hline 2 & 12 & 77 & $\begin{array}{r}1 \\
4 \\
\cdot \quad 1 \\
\\
2 \\
2 \\
2 \\
\end{array}$ & 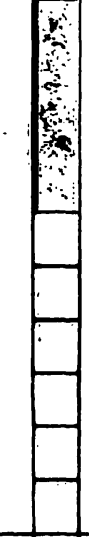 & -3 & 政 & 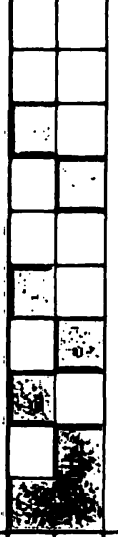 & $\begin{array}{l}2 \\
2 \\
1 \\
3 \\
1 \\
1 \\
2 \\
5 \\
3 \\
\end{array}$ & 52 & 20 \\
\hline 1 & 3 & 80 & $\begin{array}{l}1 \\
1 \\
1 \\
\end{array}$ & & 78 & 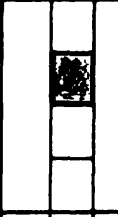 & 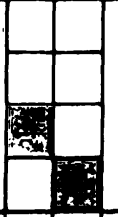 & $\begin{array}{l}3 \\
6 \\
1 \\
8 \\
\end{array}$ & 32 & 18 \\
\hline 0 & 2 & 82 & 2 & & & 1 & & 14 & 14 & 14 \\
\hline
\end{tabular}




\section{Combinations of two}

The power of differentiation for 10 combinations of two in which at least one finding is positive are shown in table 3-6, arranged according to level of efficiency. A marked increase in sensitivity (alcoholics) is evident for the combination $\gamma$-glutamyltransferase/MCV (92\% rather than $78 \%$ and $73 \%$ respectively for the individual constituents); however, the specificity (non-alcoholics) of this combination at $40 \%$ is lower than that for the individual findings.

Tab. 3-6. Combinations of two findings, at least one of which is positive.

\begin{tabular}{llll}
\hline $\begin{array}{l}\text { Constituent } \\
\text { combinations }\end{array}$ & $\begin{array}{l}\text { Sensitivity } \\
\text { alcoholics }\end{array}$ & $\begin{array}{l}\text { Specificity } \\
\text { non- } \\
\text { alcoholics } \\
(\%)\end{array}$ & $\begin{array}{l}\text { Efficiency } \\
\text { alcoholics/ } \\
\text { non-alcoholics }\end{array}$ \\
\hline Positive findings & $\vdots 1$ & 0 & \\
1 GOT/creat & 76.8 & 75.7 & 152.6 \\
$2 \gamma$-GT/creat & 90.2 & 56.3 & 146.6 \\
$3 \gamma$-GT/GOT & 79.3 & 64.3 & 143.6 \\
$4 \gamma$-GT/GPT & 80.5 & 58.6 & 139.1 \\
5 MCV/creat & 86.4 & 51.4 & 137.8 \\
6 Creat/urea-N & 87.8 & 48.6 & 136.4 \\
7 GOT/urea-N & 85.4 & 50.0 & 135.4 \\
8 GOT/MCV & 80.2 & 54.3 & 134.5 \\
9 GPT/creat & 75.6 & 57.2 & 132.8 \\
10 $\gamma$-GT/MCV & 92.6 & 40.0 & 132.6 \\
\hline
\end{tabular}

Constituent abbreviations and decision limits as in table 3-4.

The specificity improves very markedly, to $87 \%$, if the requirement is made that both findings are abnormal (tab. 3-7).

Tab. 3-7. Combinations of two findings, both of which are positive.

\begin{tabular}{llll}
\hline $\begin{array}{l}\text { Constituent } \\
\text { combinations }\end{array}$ & $\begin{array}{l}\text { Sensitivity } \\
\text { alcoholics }\end{array}$ & $\begin{array}{l}\text { Specificity } \\
\text { non- } \\
\text { alcoholics }\end{array}$ & $\begin{array}{l}\text { Efficiency } \\
\text { alcoholics/ } \\
\text { non-alcoholics }\end{array}$ \\
\hline
\end{tabular}

\begin{tabular}{llll}
\hline Positive findings & 2 & 1 & \\
$1 \gamma$-GT/urea-N & 69.5 & 78.6 & 148.1 \\
$2 \gamma$-GT/MCV & 58.0 & 87.1 & 145.2 \\
$3 \gamma$-GT/GOT & 46.3 & 94.3 & 140.6 \\
4 GOT/urea-N & 42.7 & 94.3 & 137.0 \\
5 GOT/MCV & 39.5 & 97.1 & 136.6 \\
6 MCV/urea-N & 59.3 & 77.1 & 136.4 \\
7 Creat/urea-N & 41.5 & 88.6 & 130.0 \\
$8 \gamma$-GT/creat & 36.6 & 93.0 & 129.6 \\
9 GOT/GPT & 37.8 & 91.4 & 129.2 \\
10 MCV/creat & 35.8 & 92.9 & 128.7 \\
\hline
\end{tabular}

Constituent abbreviations and decision limits as in table 3-4.

\section{Combinations of three}

For these combinations, if it is required that at least two findings be positive (tab. 3-8) the efficiency can be increased over that shown in table 3-7; specificity is then somewhat poorer, but sensitivity is much better.

Tab. 3-8. Combinations of three findings, at least two of which are positive.

\begin{tabular}{llll}
\hline Constituent combinations & $\begin{array}{l}\text { Sensitivity } \\
\text { alcoholics }\end{array}$ & $\begin{array}{l}\text { Specificity } \\
\text { non- }\end{array}$ & $\begin{array}{l}\text { Efficiency } \\
\text { alcoholics/ }\end{array}$ \\
& & alcoholics & non- \\
alcoholics
\end{tabular}

(\%) (\%)

\begin{tabular}{llll}
\hline Positive findings & 2 & 1 & \\
$1 \gamma$-GT/MCV/creat & 76.5 & 80.0 & 156.5 \\
$2 \gamma$-GT/GOT/urea-N & 75.6 & 78.6 & 154.2 \\
3 GOT/MCV/creat & 63.0 & 90.0 & 153.0 \\
4 GOT/creat/urea-N & 69.5 & 81.9 & 152.4 \\
$5 \gamma$-GT/GOT/creat & 63.4 & 88.6 & 152.0 \\
$6 \gamma$-GT/creat/urea-N & 79.3 & 70.0 & 149.3 \\
$8 \gamma$-GT/GOT/MCV & 66.7 & 81.4 & 148.1 \\
$9 \gamma$-GT/GPT/MCV & 70.4 & 72.9 & 143.2 \\
\hline
\end{tabular}

Constituent abbreviations and decision limits as in table 3-4.

\section{Combinations of four}

For the combinations shown in table 3-9 the highest sensitivity is obtained if only 2 positive findings are required, whereas the highest specificity is obtained (with a different combination) if at least 3 positive findings are required.

Tab. 3-9. Combinations of four findings.

\begin{tabular}{llll}
\hline Constituent combinations & $\begin{array}{l}\text { Sensitiv- } \\
\text { ity alco- } \\
\text { holics }\end{array}$ & $\begin{array}{l}\text { Specífic- } \\
\text { ity non- } \\
\text { alco- } \\
\text { holics }\end{array}$ & $\begin{array}{l}\text { Effi- } \\
\text { ciency } \\
\text { alco- } \\
\text { holics/ } \\
\text { non-alco- } \\
\text { holics }\end{array}$ \\
& & & \\
& $(\%)$ & $(\%)$ & \\
\hline Positive findings & 2 & 1 & \\
$1 \gamma$-GT/GOT/MCV/creat & 81.5 & 74.3 & 155.8 \\
$2 \gamma$-GT/GOT/creat/urea-N & 82.9 & 70.0 & 152.9 \\
$3 \gamma$-GT/GPT/MCV/creat & 84.0 & 65.7 & 149.6 \\
4 GOT/GPT/creat/urea-N & 75.6 & 71.4 & 147.0 \\
5 GOT/GPT/MCV/creat & 69.1 & 77.1 & 146.2 \\
6 GOT/GPT/MCV/urea-N & 85.2 & 60.0 & 145.2 \\
& & & \\
Positive findings & 3 & 2 & \\
$1 \gamma$-GT/MCV/creat/urea-N & 66.7 & 87.1 & 153.8 \\
$2 \gamma$-GT/GOT/creat/urea-N & 61.0 & 90.0 & 151.0 \\
$3 \gamma$-GT/GOT/MCV/urea-N & 61.7 & 88.6 & 150.3 \\
$4 \gamma$-GT/GOT/MCV/creat & 53.1 & 95.7 & 148.8 \\
5 GOT/MCV/creat/urea-N & 56.8 & 91.4 & 148.2 \\
\hline
\end{tabular}

Constituent abbreviations and decision lịnits as in table 3:4. 


\section{Combinations of five}

The following can be seen in table 3-10:

1. For the combination $\gamma$-glutamyltransferase, aspartate aminotransferase, alanine aminotransferase, MCV and creatinine and a requirement of at least 2 positive findings, $85 \%$ of the alcoholics are included (see sensitivity) and $64 \%$ of the non-alcoholics are identified as such with 1 positive finding at most (see specificity).

2 . For the combination $\gamma$-glutamyltransferase, aspartate aminotransferase, MCV, creatinine and urea and a limit of 3 positive findings, $96 \%$ of the non-alcoholics are included (see specificity) and $51 \%$ of the alcoholics are identified as such with at least 4 positive findings (see sensitivity).

Tab. 3-10. Combinations of five findings.

\begin{tabular}{|c|c|c|c|}
\hline Constituent combinations & $\begin{array}{l}\text { Sensitiv- } \\
\text { ity alco- } \\
\text { holics }\end{array}$ & $\begin{array}{l}\text { Specific- } \\
\text { ity non- } \\
\text { alco- } \\
\text { holics } \\
(\%)\end{array}$ & $\begin{array}{l}\text { Effi- } \\
\text { ciency } \\
\text { alco- } \\
\text { holics/ } \\
\text { non-al- } \\
\text { coholics }\end{array}$ \\
\hline Positive findings & 2 & 1 & \\
\hline$\gamma$-GT/GOT/GPT/MCV/creat & 85.2 & 64.3 & 149.5 \\
\hline Positive findings & 3 & 2 & \\
\hline $\begin{array}{l}\gamma \text {-GT/GPT/MCV/creat/urea-N } \\
\gamma \text {-GT/GOT/MCV/creat/urea-N } \\
\gamma \text {-GT/GOT/GPT/creat/urea-N }\end{array}$ & $\begin{array}{l}76.5 \\
74.1 \\
65.8\end{array}$ & $\begin{array}{l}75.7 \\
82.9 \\
84.3\end{array}$ & $\begin{array}{l}152.2 \\
157.0 \\
150.2\end{array}$ \\
\hline Positive findings & 4 & 3 & \\
\hline$\gamma$-GT/GOT/MCV/creat/urea-N & 50.6 & 95.7 & 146.3 \\
\hline
\end{tabular}

Constituent abbreviations and decision limits as in table 3-4.

Combinations of six do not bring any improvement in power of differentiation.

\subsubsection{Optimization of the decision limits: Increasing} diagnostic efficiency with reference to other patients

The decision limits were optimized first for individual constituents and then for constituent combinations.

\subsubsection{Individual conștituents}

For individual constituents only the efficiency can be optimized. The process is illustrated using the distribution of $\gamma$-glutamyltransferase activity for alcohol- ics and non-alcoholics (tab. 3-11). The effects on efficiency, sensitivity and specificity of a change in the decision limit are shown in table 3-12. The highest efficiency is obtained when the decision limit is $45 \geqslant U /$.

All individual constituents for which it was possible to obtain a maximum level of efficiency of at least 130 are shown in table 3-13 along with the optimized decision limits.

Tab. 3-11. Frequency distribution for $\gamma$-glutamyltransferase.

\begin{tabular}{|c|c|c|c|c|}
\hline Class limit & $\begin{array}{l}\text { Sensitivity } \\
\text { for the lower } \\
\text { class limit }\end{array}$ & $\begin{array}{l}\text { Alco- } \\
\text { holics } \\
\text { (N) }\end{array}$ & $\begin{array}{l}\text { Non- } \\
\text { alco- } \\
\text { holics } \\
(\mathrm{N})\end{array}$ & $\begin{array}{l}\text { Specificity } \\
\text { for the upper } \\
\text { class limit }\end{array}$ \\
\hline $0-10$ & 100 & 0 & 0 & 5.7 \\
\hline $11-20$ & 100 & 8 & 31 & 47.1 \\
\hline $21-30$ & , 90.2 & 13 & 15 & 70.0 \\
\hline $31-40$ & 74.4 & 7 & 8 & 84.3 \\
\hline $41-50$ & 65.9 & 6 & 3 & 88.6 \\
\hline $51-100$ & 59.8 & 18 & 6 & 97.1 \\
\hline $101-200$ & 39.0 & 12 & 1 & 98.6 \\
\hline$>200$ & 22.0 & 18 & 1 & 100 \\
\hline
\end{tabular}

Tab. 3-12. Example of the process of optimizing the decision limit for a single constituent with regard to efficiency, constituent: $\boldsymbol{\gamma}$-glutamyltransferase.

\begin{tabular}{llll}
\hline Criterion & $\begin{array}{l}\text { Sensitivity } \\
\text { alcoholics }\end{array}$ & $\begin{array}{l}\text { Specificity } \\
\text { non-alcoholics }\end{array}$ & $\begin{array}{l}\text { Efficiency } \\
\text { alcoholics/non- } \\
\text { alcoholics }\end{array}$ \\
$(\mathrm{U} / \mathrm{l})$ & $(\%)$ & $(\%)$ & \\
\hline$\geqslant 220$ & 22.0 & 100 & 122.0 \\
$\geqslant 60$ & 52.4 & 90.0 & 142.4 \\
$\geqslant 45$ & 63.4 & 87.1 & 150.6 \\
$\geqslant 27$ & 81.7 & 67.1 & 148.9 \\
$\geqslant 21$ & 90.2 & 51.4 & 141.7 \\
$\geqslant 11$ & 100 & 7.1 & 107.1 \\
\hline
\end{tabular}

Tab. 3-13. Decision limits optimized for maximum efficiency for six individual constituents.

\begin{tabular}{llll}
\hline Constituent & (Unit) & $\begin{array}{l}\text { Max. efficiency } \\
\text { alcoholics/ } \\
\text { non-alcoholics }\end{array}$ & Limit \\
\hline$\gamma$-GT & $(\mathrm{U} / \mathrm{l})$ & 151 & $\geqslant 45$ \\
GOT & $(\mathrm{U} / \mathrm{l})$ & 143 & $\geqslant 16$ \\
MCV & $(\mathrm{f})$ & 138 & $\geqslant 95$ \\
Urea-N & $(\mathrm{mmol} / \mathrm{l})$ & 137 & $\leqslant 4.3$ \\
Creat & $(\mu \mathrm{mol} / \mathrm{l})$ & 134 & $\leqslant 70.7$ \\
GPT & $(\mathrm{U} / \mathrm{l})$ & 130 & $\geqslant 15$ \\
\hline
\end{tabular}

Constituent abbreviations as in table 3-4. 


\subsubsection{Combinations}

The following can be seen in table 3-14:

1. For combination no. 5 , consisting of the 6 constituents $\gamma$-glutamyltransferase, aspartate aminotransferase, alanine aminotransferase, $\mathrm{MCV}$, creatinine and urea, $83 \%$ of the alcoholics can be included if there are at least 5 positive findings (see sensitivity) and $89 \%$ of the non-alcoholics can be recognized as such (see specificity) if there are 4 positive findings at the most. This means that this combination with these restrictions can be used to detect the non-alcoholics.

2. The complementary situation for the same combination is that $89 \%$ of the non-alcoholics can be included with 4 positive findings at the most (see specificity) and $83 \%$ of the alcoholics can be identified as such if there are at least 5 positive findings. This means that this combination in this form can be used to detect the alcoholics. The two applications complement each other if both the sensitivity of $83 \%$ and the specificity of $89 \%$ are regarded as being high enough.

3. For the combination of $\gamma$-glutamyltransferase, aspartate aminotransferase, the ratio aspartate/alanine aminotransferase, MCV, creatinine and urea, $86 \%$ of the alcoholics are included if at least 5 positive findings are required (see sênsitivity) and $87 \%$ of the non-alcoholics can be identified as such (see specificity) if there are at least 4 positive findings.

If a sensitivity or specificity of $100 \%$ is required, then for a combination of six either a maximum sensitivity of $59 \%$ or a maximum specificity of $53 \%$ can be attained. Considering the marked overlapping of the distributions, such requirements must be regarded as unrealistically severe. Therefore in tables 3-15 and 3-16 respectively specificity and sensitivity were set at $95 \%$.

Tab. 3-14. Examples of decision limits optimized for maximum efficiency for various combinations of constituents.

\begin{tabular}{llllll}
\hline $\begin{array}{l}\text { Constituent } \\
\text { combination }\end{array}$ & (Unit) & Limit & $\begin{array}{l}\text { Criterion for } \\
\text { positive test, alcoholics } \\
\text { minimum no. }\end{array}$ & $\begin{array}{l}\text { Specificity } \\
\text { non-alcoholics }\end{array}$ & $\begin{array}{l}\text { Efficiency } \\
\text { alcoholics/ } \\
\text { non-alcoholics }\end{array}$ \\
& & nonive & &
\end{tabular}

(\%)

\begin{tabular}{|c|c|c|c|c|c|c|c|}
\hline 1 & $\begin{array}{l}\gamma-G T \\
M C V\end{array}$ & $\begin{array}{l}(\mathrm{U} / \mathrm{l}) \\
(\mathrm{fl})\end{array}$ & $\begin{array}{l}\geqslant 18 \\
\geqslant 90\end{array}$ & 2 & 90.1 & 68.6 & 158.7 \\
\hline $2 a$ & $\begin{array}{l}\gamma-G T \\
\text { GOT } \\
\text { MCV }\end{array}$ & $\begin{array}{l}(\mathrm{U} / \mathrm{l}) \\
(\mathrm{U} / \mathrm{l}) \\
(\mathrm{fl})\end{array}$ & $\begin{array}{l}\geqslant 18 \\
\geqslant 19 \\
\geqslant 90\end{array}$ & 2 & 93.8 & 67.1 & $\because \quad \cdots \cdots 161.0$ \\
\hline $2 b$ & $\begin{array}{l}\gamma-G T \\
\text { GOT } \\
\text { MCV }\end{array}$ & $\begin{array}{l}(\mathrm{U} / \mathrm{l}) \\
(\mathrm{U} / \mathrm{l}) \\
(\mathrm{fl})\end{array}$ & $\begin{array}{l}\geqslant 18 \\
\geqslant 11 \\
\geqslant 90\end{array}$ & 3 & 85.2 & $\begin{array}{c}\cdot \\
80.0\end{array}$ & 165.2 \\
\hline 3 & $\begin{array}{l}\gamma \text {-GT } \\
\text { GOT } \\
\text { MCV } \\
\text { Urea-N }\end{array}$ & $\begin{array}{l}(\mathrm{U} / \mathrm{l}) \\
(\mathrm{U} / \mathrm{l}) \\
(\mathrm{fl}) \\
(\mathrm{mmol} / \mathrm{l})\end{array}$ & $\begin{array}{l}\geqslant 18 \\
\geqslant 9 \\
\geqslant 89 \\
\leqslant 5.4\end{array}$ & 4 & 85.2 & 82.9 & 168.0 \\
\hline 4 & $\begin{array}{l}\gamma-\mathrm{GT} \\
\text { GOT } \\
\text { MCV } \\
\text { Creat } \\
\text { Urea-N }\end{array}$ & $\begin{array}{l}(\mathrm{U} / \mathrm{l}) \\
(\mathrm{U} / \mathrm{l}) \\
(\mathrm{fl}) \\
(\mu \mathrm{mol} / \mathrm{l}) \\
(\mathrm{mmol} / \mathrm{l})\end{array}$ & $\begin{array}{l}\geqslant 19 \\
\geqslant 15 \\
\geqslant 94 \\
\leqslant 68.1 \\
\leqslant 2.9\end{array}$ & 3 & 81.5 & 88.6 & 170.0 \\
\hline 5 & $\begin{array}{l}\gamma \text {-GT } \\
\text { GOT } \\
\text { GPT } \\
\text { MCV } \\
\text { Creat } \\
\text { Urea-N }\end{array}$ & $\begin{array}{l}(\mathrm{U} / \mathrm{l}) \\
(\mathrm{U} / \mathrm{l}) \\
(\mathrm{U} / \mathrm{l}) \\
(\mathrm{fl}) \\
(\mu \mathrm{mol} / \mathrm{l}) \\
(\mathrm{mmol} / \mathrm{l})\end{array}$ & $\begin{array}{l}\geqslant 26 \\
\geqslant 10 \\
\geqslant 9 \\
\geqslant 93 \\
\leqslant 67.2 \\
\leqslant 6.4\end{array}$ & 5 & 82.7 & 88.6 & 171.3 \\
\hline 6 & $\begin{array}{l}\gamma-G T \\
\text { GOT } \\
\text { GOT/GPT } \\
\text { MCV } \\
\text { Creat } \\
\text { Urea-N }\end{array}$ & $\begin{array}{l}(\mathrm{U} / \mathrm{l}) \\
(\mathrm{U} / \mathrm{l}) \\
(\mathrm{U} / \mathrm{l}) \\
(\mathrm{fl}) \\
(\mu \mathrm{mol} / \mathrm{l}) \\
(\mathrm{mmol} / \mathrm{l})\end{array}$ & $\begin{array}{l}\geqslant 27 \\
\geqslant 9 \\
\geqslant 0.63 \\
\geqslant 89 \\
\leqslant 70.7 \\
\leqslant 6.4\end{array}$ & 5 & 86.4 & 87.1 & 173.6 \\
\hline
\end{tabular}


The following can be seen in tables 3-15 and 3-16:

1 . For the combination of $\gamma$-glutamyltransferase, aspartate aminotransferase, alanine aminotransferase, $\mathrm{MCV}$, creatinine and urea, if $95.7 \%$ of the non-alcoholics are included, $67 \%$ of the alcoholics with at least 4 positive findings will be detected (see maximum sensitivity, table 3-15).

2. For the same combination, if $95.1 \%$ of the alcoholics are included, $74 \%$ of the non-alcoholics with 3 positive findings at the most will be identified as such (see maximum specificity, table 3-16).

The decision limits for the two procedures are different.

\subsection{Clinical laboratory findings as markers of alcoholism and alcohol abuse}

Because of the increase in alcoholism over the last 3 decades, numerous attempts have been made during

Tab. 3-15. Examples of decision limits optimized for maximum sensitivity of constituent combinations.

Required specificity: $95.7 \%$ (non-alcoholics)

\begin{tabular}{|c|c|c|c|c|}
\hline $\begin{array}{l}\text { Constituent } \\
\text { combination }\end{array}$ & (Unit) & Limit & $\begin{array}{l}\text { Mini- } \\
\text { mum } \\
\text { no. of } \\
\text { posi- } \\
\text { tive } \\
\text { tests }\end{array}$ & $\begin{array}{l}\text { Maximum } \\
\text { sensitivity } \\
(\%) \\
\text { alcoholics }\end{array}$ \\
\hline $\begin{array}{l}1 \gamma-G T \\
M C V\end{array}$ & $\begin{array}{l}(\mathrm{U} / \mathrm{l}) \\
(\mathrm{fl})\end{array}$ & $\begin{array}{l}\geqslant 67 \\
\geqslant 84\end{array}$ & 2 & 48.2 \\
\hline $\begin{array}{c}2 \gamma-\mathrm{GT} \\
\mathrm{GOT} \\
\mathrm{MCV}\end{array}$ & $\begin{array}{l}(\mathrm{U} / \mathrm{l}) \\
(\mathrm{U} / \mathrm{l}) \\
(\mathrm{fl})\end{array}$ & $\begin{array}{l}\geqslant 24 \\
\geqslant 15 \\
\geqslant 92\end{array}$ & 3 & 55.6 \\
\hline $\begin{array}{c}3 \gamma-G \bar{T} \\
\text { GOT } \\
\text { MCV } \\
\text { Urea-N }\end{array}$ & $\begin{array}{l}(\dot{U} / \mathbf{l}) \\
(\mathrm{U} / \mathrm{l}) \\
(\mathrm{fl}) \\
(\mathrm{mmol} / \mathrm{l})\end{array}$ & $\begin{array}{l}\geqslant 29 \\
\geqslant 9 \\
\geqslant 92 \\
\leqslant 4.6\end{array}$ & 4 & 60.5 \\
\hline $\begin{array}{l}4 \text { } \gamma \text {-GT } \\
\text { GOT } \\
\text { MCV } \\
\text { Creat } \\
\text { Urea-N }\end{array}$ & $\begin{array}{l}(\mathrm{U} / \mathrm{l}) \\
(\mathrm{U} / \mathrm{l}) \\
(\mathrm{fl}) \\
(\mu \mathrm{mol} / \mathrm{l}) \\
(\mathrm{mmol} / \mathrm{l})\end{array}$ & $\begin{array}{l}\geqslant 62 \\
\geqslant 16 \\
\geqslant 95 \\
\leqslant 61.9 \\
\leqslant 2.9\end{array}$ & 3 & 65.4 \\
\hline $\begin{array}{l}5 \text { y-GT } \\
\text { GOT } \\
\text { GPT } \\
\text { MCV } \\
\text { Creat } \\
\text { Urea-N }\end{array}$ & $\begin{array}{l}(\mathrm{U} / \mathrm{l}) \\
(\mathrm{U} / \mathrm{l}) \\
(\mathrm{U} / \mathrm{l}) \\
(\mathrm{fl}) \\
(\mu \mathrm{mol} / \mathrm{l}) \\
(\mathrm{mmol} / \mathrm{l})\end{array}$ & $\begin{array}{l}\geqslant 27 \\
\geqslant 15 \\
\geqslant 11 \\
\geqslant 97 \\
\leqslant 61.9 \\
\leqslant 2.9\end{array}$ & 4 & 66.7 \\
\hline $\begin{array}{l}6 \text {-GT } \\
\text { GOT } \\
\text { GOT/GPT } \\
\text { MCV } \\
\text { Creat } \\
\text { Urea-N }\end{array}$ & $\begin{array}{l}(\mathrm{U} / \mathrm{l}) \\
(\mathrm{U} / \mathrm{l}) \\
(\mathrm{U} / \mathrm{l}) \\
(\mathrm{fl}) \\
(\mu \mathrm{mol} / \mathrm{l}) \\
(\mathrm{mmol} / \mathrm{l})\end{array}$ & $\begin{array}{l}\geqslant 18 \\
\geqslant 9 \\
\geqslant 1.05 \\
\geqslant 90 \\
\leqslant 67.2 \\
\leqslant 6.4\end{array}$ & 5 & 67.9 \\
\hline
\end{tabular}

Constituent abbreviations as in table 3-4. the past 10 years to find combinations of clinical chemical findings that would be useful in the detection or exclusion of alcohol abuse (23). Table 3-17 shows the combinations of findings suggested in selected papers published in the last 3 years. In some of the papers alcoholics were compared with "healthy" persons, with the result that the figures on discrimination of alcoholics from non-alcoholics are too optimistic. A realistic picture is obtained only if alcoholics are compared with non-alcoholics who have other disorders that can lead to changes in clinical chemical parameters.

Furthermore, from the data structure of the analytical results for alcoholics and non-alcoholics reported here it can be seen that for most of the parameters studied the prerequisites for use of linear or quadratic discriminant analysis are not fulfilled (see Section 2.5.3).

Tab. 3-16. Examples of decision limits optimized for maximum specificity of constituent combinations. Required sensitivity: $95.1 \%$ (alcoholics)

\begin{tabular}{llll}
\hline $\begin{array}{l}\text { Constituent } \\
\text { combination }\end{array}$ & (Unit) & Limit & Mini- Maximum \\
& & mum specificity \\
& & no. of $(\%)$ \\
& & posi- non- \\
& & tive alcoholics \\
& & tests
\end{tabular}

\begin{tabular}{|c|c|c|c|c|}
\hline $\begin{array}{l}1 \underset{\mathrm{MCV}}{\gamma-\mathrm{GT}} \\
\end{array}$ & $\begin{array}{l}(\mathrm{U} / \mathrm{l}) \\
\text { (fl) }\end{array}$ & $\begin{array}{l}\geqslant 13 \\
\geqslant 89\end{array}$ & 2 & 48.6 \\
\hline $\begin{array}{c}2 \gamma-\mathrm{GT} \\
\mathrm{GOT} \\
\mathrm{MCV}\end{array}$ & $\begin{array}{l}(\mathrm{U} / \mathrm{l}) \\
(\mathrm{U} / \mathrm{l}) \\
(\mathrm{fl})\end{array}$ & $\begin{array}{l}\geqslant 16 \\
\geqslant 19 \\
\geqslant 90\end{array}$ & 2 & 60.0 \\
\hline 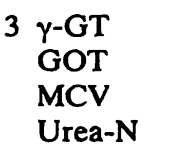 & $\begin{array}{l}(\mathrm{U} / \mathrm{l}) \\
(\mathrm{U} / \mathrm{l}) \\
(\mathrm{fl}) \\
(\mathrm{mmol} / \mathrm{l})\end{array}$ & $\begin{array}{l}\geqslant 15 \\
\geqslant 14 \\
\geqslant 90 \\
\leqslant 5.0\end{array}$ & 3 & 65.7 \\
\hline $\begin{array}{l}4 \text { y-GT } \\
\text { GOT } \\
\text { MCV } \\
\text { Creat } \\
\text { Urea-N }\end{array}$ & $\begin{array}{l}(\mathrm{U} / \mathrm{l}) \\
(\mathrm{U} / \mathrm{l}) \\
(\mathrm{fl}) \\
(\mu \mathrm{mol} / \mathrm{l}) \\
(\mathrm{mmol} / \mathrm{l})\end{array}$ & $\begin{array}{l}\geqslant 18 \\
\geqslant 10 \\
\geqslant 94 \\
\leqslant 70.7 \\
\leqslant 2.5\end{array}$ & 3 & 70.0 \\
\hline $\begin{array}{l}5 \text {-GT } \\
\text { GOT } \\
\text { GPT } \\
\text { MCV } \\
\text { Creat } \\
\text { Urea-N }\end{array}$ & $\begin{array}{l}(\mathrm{U} / \mathrm{l}) \\
(\mathrm{U} / \mathrm{l}) \\
(\mathrm{U} / \mathrm{l}) \\
(\mathrm{fl}) \\
(\mu \mathrm{mol} / \mathrm{l}) \\
(\mathrm{mmol} / \mathrm{l})\end{array}$ & $\begin{array}{l}\geqslant 18 \\
\geqslant 10 \\
\geqslant 9 \\
\geqslant 97 \\
\leqslant 66.3 \\
\leqslant 4.3\end{array}$ & 4 & 74.3 \\
\hline $\begin{array}{l}6 \text { y-GT } \\
\text { GOT } \\
\text { GOT/GPT } \\
\text { MCV } \\
\text { Creat } \\
\text { Urea-N }\end{array}$ & $\begin{array}{l}(\mathrm{U} / \mathrm{l}) \\
(\mathrm{U} / \mathrm{l}) \\
(\mathrm{U} / \mathrm{l}) \\
(\mathrm{fl}) \\
(\mu \mathrm{mol} / \mathrm{l}) \\
(\mathrm{mmol} / \mathrm{l})\end{array}$ & $\begin{array}{l}\geqslant 25 \\
\geqslant 10 \\
\geqslant 0.60 \\
\geqslant 90 \\
\leqslant 80.4 \\
\leqslant 6.4\end{array}$ & 5 & 72.9 \\
\hline
\end{tabular}

Constituent abbreviations as in table 3-4. 
Tab. 3-17. Combinations of clinical chemical findings as markers of alcohol abuse and alcoholism.

\begin{tabular}{|c|c|c|c|c|c|c|c|c|}
\hline \multirow[t]{2}{*}{ System analysed } & \multicolumn{8}{|c|}{ Investigator; year (reference) } \\
\hline & $\begin{array}{l}\text { Whitehead } \\
\text { et al. }\end{array}$ & $\begin{array}{l}\text { Whitfield } \\
\text { et al. }\end{array}$ & $\begin{array}{l}\text { Ryback } \\
\text { et al. }\end{array}$ & $\begin{array}{l}\text { Wisser } \\
\text { \& Knoll }\end{array}$ & $\begin{array}{l}\text { Chalmers } \\
\text { et al. }\end{array}$ & $\begin{array}{l}\text { Eckardt } \\
\text { et al. }\end{array}$ & & $\begin{array}{l}\text { Gluud } \\
\text { et al. }\end{array}$ \\
\hline Constituent & $\begin{array}{l}1978 \\
(24)\end{array}$ & $\begin{array}{l}1978 \\
(25)\end{array}$ & $\begin{array}{l}1980 \\
(26)\end{array}$ & $\begin{array}{l}1980 \\
(27)\end{array}$ & $\begin{array}{l}1981 \\
(28)\end{array}$ & $\begin{array}{l}1981 \\
(29)\end{array}$ & $\therefore$ & $\begin{array}{l}1981 \\
(30)\end{array}$ \\
\hline
\end{tabular}

Whole blood

Sedimentation rate

Haemoglobin

Haematocrit

Erythrocytes

MCV

Reticulocytes

Leukocytes

Differential blood count

Thrombocytes

Capillary blood

Glucose

\section{Serum}

Total protein

Albumin

$\gamma$-Globulin

Bilirubin

Uric acid

Sodium

Potassium

Calcium

Chloride

Phosphorus, inorg.

Magnesium

Iron

Copper

Cholesterol

Triglycerides

Creatinine

Urea

$\gamma$-Glutamyltransferase

Aspartate aminotransferase

Alanine aminotransferase

Cholinesterase

Alkaline phosphatase

Glutamate dehydrogenase

Creatine kinase

Lactate dehydrogenase $\mathbf{x x x}$

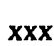

$\mathbf{x x x}$

$\mathbf{x x x}$

$\mathbf{x x x}$

$\mathbf{x x x}$

$\mathbf{x x x}$

$\mathbf{x x x}$

$\mathbf{x x x}$

$\mathbf{x x x}$

$\mathbf{x x x}$

$\mathbf{x x x}$

$\mathbf{x x x}$

$\mathbf{x x x}$

$\mathbf{X X X}$

XXX

XXX

xxx

$\begin{array}{ccc} & \mathbf{x x x} & \mathbf{x x x} \\ & & \mathbf{x x x} \\ \mathbf{x x x} & \mathbf{x x x} & \\ \mathbf{x x x} & \mathbf{x x x} & \mathbf{x x x} \\ & & \\ & & \mathbf{x x x}\end{array}$

$\mathbf{x x x}$

$\mathbf{X x X}$

$\mathbf{x x x}$

X

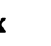


In our statistical evaluations, marked overlapping of distributions was also found for combinations of constituents. As a result, a complete separation of alcoholics and non-alcoholics is not possible with any procedure. The combinations of six with optimized decision limits shown in Section 3.2.4.2 appear to us to be the best combinations of clinical laboratory findings for the differentiation of alcoholics and nonalcoholics in patient populations.

The levels of discrimination reported by Ryback et al. (26) and Eckardt et al. (29) appear to us to be unrealistic. This is because

(1) alcoholics were compared with individuals who were apparently healthy and

(2) quadratic discriminant analysis was used (the structure of our data and our results indicate that the prerequisites for this procedure are not fulfilled).

\section{Conclusions}

The investigations reported here were performed on men only. The conclusions are therefore valid for men only. In an analogous study with the same design but with women as subjects all tests have been completed and the data are now being evaluated.

With regard to the purpose of the study the following has been learned:

\section{Detection of alcoholism}

Detection of alcoholism on the basis of a statistical discrimination procedure is synonomous with exclusion of non-alcoholism.

If the 5 parameters $\gamma$ =glutamyltransferase ( $\geqslant 28 \mathrm{U} / 1)$, aspartate aminotransferase $(\geqslant 18 \mathrm{U} / \mathrm{A})$, alanine aminotransferase $(\geqslant 22 \mathrm{U} / \mathrm{l}), \mathrm{MCV}(\geqslant 96 \mathrm{fl})$ and creatinine $(\leqslant 66.3 \mu \mathrm{mol} / \mathrm{l})$ are studied, alcoholism can be detected on the basis of 2 or more of the results being outside the conventional decision limits given in parentheses (tab. 3-10). The diagnostic sensitivity is $85 \%$, the diagnostic specificity $64 \%$ and thus the diagnostic efficiency 149.

If the decision limits are optimized and the sensitivity maintained about as above, the specificity can be increased to about $89 \%$ and the efficiency to 171 for 6 parameters, no ratio, or 174 for 6 parameters with ratio (tab. 3-14).
Thus it appears possible to detect alcoholism with a high degree of probability using simple means and without the cooperation of the patient.

\section{Exclusion of alcoholism}

The exclusion of alcoholism on the basis of a statistical discrimination procedure is synonymous with the detection of non-alcoholism.

If the 5 parameters $\gamma$-glutamyltransferase $(<28 \mathrm{U} / \mathrm{l})$, aspartate aminotransferase $(<18 \mathrm{U} / \mathrm{l}), \mathrm{MCV}(<96$ fl), creatinine $(>66.3 \mu \mathrm{mol} / \mathrm{l})$ and urea $(>5.0$ $\mathrm{mmol} / \mathrm{l}$ ) are studied, alcoholism can be detected if 4 or more of the results are outside the conventional decision limits given in parentheses (tab. 3-10). For this combination the diagnostic specificity is $96 \%$, the diagnostic sensitivity $50 \%$ and thus the efficiency 146.

If the decision limits are optimized and the specificity maintained as above, the sensitivity can be increased to about $67 \%$ (tab. 3-15). Efficiency can be increased to 171 for 6 parameters, no ratio, or 174 for 6 parameters with ratio (tab. 3-14).

It thus appears to be possible to exclude alcohol abuse very quickly with a high level of probability, using simple investigations.

3. It is essential that these patterns of findings in alcoholics and non-alcoholics be validated with patients who have disorders of the liver, the blood and blood-forming organs, the kidneys and the circulatory system. A validation study with men is in progress.

\section{Acknowledgments}

The extensive study reported here would not have been possible without the efficient collaboration of three departments within the Max-Planck-Institut für Psychiatrie.

The patients were selected and examined by Dr. Sigrid Seidel and Dr. V. Geiger of the Psychiatric Outpatient Department. The clinical chemical and haematological studies were performed in the routine laboratory of the Department of Clinical Chemistry. Special thanks are due to the head technologist, Ms. Liselotte Hofmann, to Mrs. Elisabeth Stiegler (née Roesch) and to all of the other laboratory technicians.

Ms. Ingrid Bickert and Ms. Eva Müller (Department of Biostatistics) carried out the data processing, compiled the tables and prepared the diagrams with great attention to detail. The reference list was compiled and the manuscript typed with great care by Ms. Elisabeth Geirhos and Ms. Ursula Grau.

Professors Ellen Schmidt and Johannes Büttner of Hannover were kind enough to discuss the results and their evaluation with us; they made valuable suggestions for the future validation of our findings.

We wish to express our appreciation to all concerned. 


\section{References}

1. Athen, D. \& Schranner, B. (1981)

Zur Häufigkeit von Alkoholikern im Krankengut einer Medizinischen Klinik. In: Behandlung der Sucht und des Mißbrauchs chemischer Stoffe (Keup, W. Ed.), Georg Thieme Verlag, Stuttgart, New York, pp. 43-47.

2. Auerbach, P. \& Melchertsen, K. (1981)

Zur Häufigkeit des Alkoholismus stationär behandelter $\mathrm{Pa}$ tienten aus Lübeck. Schleswig-Holsteinisches Ärzteblatt No. 5, 223-227.

3. Edwards, G., Orford, J., Egert, S., Guthrie, S., Hawker, A., Hensman, C., Mitcheson, M., Oppenheimer, E. \& Taylor, C. (1977)

Alcoholism: A controlled trial of "treatment" and "advice". J. Stud. Alc. 38, 1004-1031.

4. Clark, P. M. S. \& Kricka, L. J. (1980)

Medical Consequences of Alcohol Abuse. John Wiley \& Sons, New York, Chichester, Brisbane, Toronto.

5. Teschke, R. \& Lieber, C. S. (1981)

Alkohol und Organschäden: Epidemiologische, klinische, biochemische und therapeutische Aspekte. Verlag Gerhard Witzstrock, Baden-Baden, Cologne, New York.

6. Lieber, C. S. (ed.) (1977)

Metabolic Aspects of Alcoholism. MTP Press Limited, Lancaster.

7. Feuerlein, W., Ringer, Ch., Küfner, H. \& Antons, K. (1977) Diagnose des Alkoholismus. Der Münchner AlkoholismusTest (MALT).

Münch. Med. Wochenschr. 119, 1275-1282.

8. Feuerlein, W., Küfner, H., Ringer, Ch. \& Antons, K. (1979) Münchner Alkoholismustest (MALT). Beltz Verlag, Weinheim.

9. Shaw, S., Stimmel, B. \& Lieber, C. S. (1976)

Plasma alpha amino- $n$-butyric acid to leucine ratio: An empirical biochemical marker of alcoholism.

Science 194, 1057-1058.

10. Stamm, D., Hansert, E. \& Feuerlein, W. (1984)

Excessive consumption of alcohol in men as a biological influence factor in clinical laboratory investigations. J. Clin. Chem. Clin. Biochem. 22, 65-77.

11. Gräsbeck, R., Siest, G., Wilding, P., Williams, G. Z. \& Whitehead, T. P. (1978)

Provisional recommendations on the theory of reference values (1978) Part 1. The concept of reference values.

Clin. Chim. Acta 87, F459-F465;

reprinted in J. Clin. Chem. Clin. Biochem. 17, 337-339 (1979) and

Clin. Chem. 25, 1506-1508 (1979).

12. Gräsbeck, R. \& Alström, T. (eds.) (1981)

Reference Values in Laboratory Medicine. John Wiley \& Sons, Chichester, New York, Brisbane, Toronto, Singapore.

13. Immich, H. (1974)

Medizinische Statistik - Eine Einführungsvorlesung. F. K. Schattauer Verlag, Stuttgart, New York.

14. Hansert, E., Federkiel, H. \& Stamm, D. (in press) A new procedure for discriminating between two patient populations using multivariate decision limits - Application in the detection and exclusion of alcoholism based on clinical laboratory findings.

J. Clin. Chem. Clin. Biochem.

15. Solberg, H. E. (1975)

Discriminant analysis in clinical chemistry (editorial).

Scand. J. Clin. Lab. Invest. 35, 705-712.

15a. Stoermer, H. (1964)

Ein Test zum Erkennen von Normalverteilungen.

Z. Wahrscheinlichkeitstheorie $2,420-428$.

16. Buening, H. \& Trenkler, G. (1978) Nichtparametrische statistische Methoden. Walter de Gruy-
ter, Berlin, New York.
17. Galen, R. S. \& Gambino, S. R. (1975)

Beyond Normality: The Predictive Value and Efficiency of Medical Diagnoses. John Wiley \& Sons, New York, London, Sydney, Toronto.

18. Büttner, J. (1977)

Die Beurteilung des diagnostischen Wértes klinisch-chemischer Untersuchungen.

J. Clin. Chem. Clin. Biochem. 15, 1-12.

19. Lang, H., Rick, W. \& Büttner, H. (eds.) (1980)

Validität klinisch-chemischer Befunde. Springer-Verlag, Berlin, Heidelberg, New York.

20. Lang, H., Rick, W. \& Büttner, H. (eds.) (1982) Strategien für den Einsatz klinisch-chemischer Untersuchungen. Springer-Verlag, Berlin, Heidelberg, New York.

21. Stamm, D. (1982)

A new concept for quality control of clinical laboratory investigations in the light of clinical requirements and based on reference method values.

J. Clin. Chem. Clin. Biochem. 20, 817-824.

22. Büttner, H., Hansert, E. \& Stamm, D. (1974)

Statistical analysis, control and assessment of experimental results.

In: Methods of Enzymatic Analysis (Bergmeyer, H. U. ed.), 2nd English edition, translated from the 3rd German edition, Vol. 1. Verlag Chemie, Weinheim; Academic Press, New York, London, pp. 318-395.

23. Holt, S., Skinner, H. A. \& Israel, Y. (1981)

Early identification of alcohol abuse: 2 . Clinical and laboratory indicators.

Canad. Med. Ass. J. 124, 1279-1295.

- 24. Whitehead, T. P., Clarke, C. A. \& Whitfield, A. G. W. (1978)

Biochemical and haematological markers of alcohol intake. Lancet $I, 978-981$.

25. Whitfield, J. B., Hensley, W. J., Bryden, D. \& Gallagher, H. (1978)

Estimation of alcohol intake from laboratory results.

Ann. Clin. Biochem. 15, 304-306.

26. Ryback, R. S., Eckardt, M. J. \& Pautler, C. P. (1980) Biochemical and hematological correlates of alcoholism. Res. Commun. Chem. Path. Pharmacol: 27, 533-550.

27. Wisser, H. \& Knoll, E. (1980)

Die diagnostische Wertigkeit von labormedizinischen Parametern bei Alkoholismus und Exposition mit halogenierten aliphatischen Kohlenwasserstoffen.

Ärztl. Lab. 26, 78-82.

28. Chalmers, D. M., Rinsler, M. G., MacDermott, S., Spicer, C. C. \& Levi, A. J. (1981)

Biochemical and haematological indicators of excessive alcohol consumption.

Gut 22, 992-996.

29. Eckardt, M. J., Ryback, R. S., Rawlings, R. R. \& Graubard, B. I. (1981)

Biochemical diagnosis of alcoholism: A test of the discriminating capabilities of $\gamma$-glutamyl transpeptidase and mean corpuscular volume.

J. Amer. Med. Ass. 246, 2707-2710.

30. Gluud, C., Andersen, I., Dietrichson, O., Gluud, B.; Jacobsen, A. \& Juhl, E. (1981)

Gamma-glutamyltransferase, aspartate aminotransferase and alkaline phosphatase as markers of alcohol consumption in out-patient alcoholics.

Europ. J. Clin. Invest. 11, 171-176.

Professor Dr. Dr. D. Stamm

Leiter der Abteilung für Klinische Chemie

Max-Planck-Institut für Psychiatrie

Kraepelinstraße 10

D-8000 München 40 